\title{
PERLINDUNGAN KONSUMEN DALAM MENGGUNAKAN JASA MODIFIKASI BENGKEL KUSTOM di RICH RICHIE RIDE GARAGE
}

\author{
Diva Satria Bhaskara \\ E-mail: divsatria@gmail.com \\ Mahasiswa Fakultas Hukum Universitas Sebelas Maret \\ Moch. Nadjib Imanullah \\ E-mail: imanullahnajib@yahoo.com \\ Dosen Fakultas Hukum Universitas Sebelas Maret
}

\begin{abstract}
This article wants to find out how Rich Richie Ride Garage gives consumer right protection to their consumer, some times the consumer who cuztomised their bike disappointed for Rich Richie Ride Garage because their expectation and ideas of their custom bike isn't accordance with the reality. In this legal writing, the Author using non doctrinal legal research or empiric legal research. The nature of empiric showed by data collection. On empirical research that was examined initially secondary legal, then followed by research towards primary legal in field. The result of research and review there are still things that harmful the consumer like progress of modification takes a long time, the result of work isn, accordance with the deal, do something prohibited in the deal. Unfortunately the consumer lack of knowledge about consumer right protection wich cause them to not fully understand the rights belongs them. They even gave up their rights because of their ignorance about consumer right protection.
\end{abstract}

Keywords: Custom Workshop; Consumer Right Protection; Modification Services

\begin{abstract}
Abstrak
Artikel ini bertujuan untuk mengetahui bagaimana bentuk perlindungan konsumen yang diberikan oleh Rich Richie Ride Garage terhadap para konsumennya, terkadang konsumen dari pemilik kendaraan yang menggunakan jasa dari bengkel kustom merasa kecewa dengan pengerjaan yang tidak sesuai antara hasil jadi kendaraan tersebut dengan rancangan ide-ide dari pemilik kendaraan. Untuk mencapai tujuan tersebut maka dilakukan penelitian hukum non doktrinal atau penelitian empiris. Dalam hal ini sifat empirisme ditunjukkan dengan perolehan data yang terkait dengan perlindungan konsumen dari Rich Richie Ride Garage. Pada penelitian hukum sosiologis atau empiris, maka yang diteliti pada awalnya adalah data sekunder, kemudian dilanjutkan dengan penelitian terhadap data primer di lapangan, atau terhadap masyarakat. Dari hasil penelitian dan kajian diketahui masih terjadi wanprestasi berupa hasil yang tidak sesuai dari perjanjian, melakukan pekerjaan yang dilarang dalam perjanjian, perjanjian tidak dipenuhi secara keseluruhan, dan yang utama dalam masalah waktu pengerjaan yang merugikan para konsumen. Tetapi yang sangat disayangkan adalah ketidaktahuan para konsumen mengenai aturan hukum perlindungan konsumen menyebabkan para konsumen kurang memahami hak-hak yang seharusnya didapatkan. Bahkan, terdapat pula konsumen yang melepaskan haknya dalam hal penggantian ganti rugi oleh penjual dikarenakan ketidaktahuan konsumen akan hak perlindungan hukum bagi konsumen
\end{abstract}

Kata Kunci: Bengkel Kustom; Perlindungan Konsumen; Jasa Modifikasi

\section{A. Pendahuluan}

Perkembangan dalam dunia otomotif sangat pesat. Dengan memodifikasi kendaraan, maka akan meningkatkan value dari kendaraan tersebut baik dari estetika, performa maupun sosial dari pemilik motor tersebut, pemilik motor lebih percaya diri dalam mengendarai motor hasil modifikasinya. Modifikasi kendaraan bermotor adalah perubahan terhadap spesifikasi teknis dimensi, mesin, dan/ atau kemampuan daya angkut kendaraan bermotor (Peraturan Pemerintah Republik Indonesia 
Nomor 55 Tahun 2012). Banyaknya peminat, penggiat maupun pembuat modifikasi kendaraan menimbulkan berbagai macam aliran modifikasi yang pada akhirnya menjadi sebuah budaya atau gaya hidup, salah satunya adalah Custom Culture/Kustom Kulture. Di Surakarta sendiri, aliran Kustom Kulture tumbuh secara cepat dan mampu menarik perhatian pecinta otomotif dalam skala besar. Perkembangan Kustom Kulture juga menarik banyak penggiat usaha kecil dan menengah untuk ambil bagian. Jasa adalah produk yang tak berwujud, yang berupa tindakan atau kegiatan yang dilakukan oleh penyediaan jasa, yang dapat dirasakan dan diambil manfaatnya oleh pihak pengguna jasa (Budi Harto, 2015 : 20) salah satu bengkel modifikasi kustom terkemuka di kota Solo adalah Rich Richie Ride Garage. Dalam praktiknya, yang menjadi masalah terkadang konsumen dari pemilik kendaraan yang menggunakan jasa dari bengkel kustom merasa kecewa dengan pengerjaan yang tidak sesuai antara hasil jadi kendaraan tersebut dengan rancangan ide - ide dari pemilik kendaraan, selain itu masa waktu proses pengerjaan terkadang tidak sesuai seperti yang dibicarakan di awal, sehingga konsumen pengguna jasa bengkel kustom merasa kecewa. Upaya menjaga harkat dan martabat konsumen perlu didukung peningkatan kesadaran, pengetahuan, kepedulian, kemampuan, dan kemandirian konsumen untuk melindungi diri serta menumbuhkembangkan sikap pelaku usaha yang bertanggung jawab (Wahyu Simon T, 2016 : 58). Mengetahui kualitas penilaian jasa dari konsumen dapat membantu penyedia jasa meningkatkan kualitas jasanya (Munawaroh Munijati, 2005 : 133). Berdasarkan fenomena tersebut, penulis ingin mengetahui bagaimana peran Rich Richie Ride Garage memberikan perlindungan terhadap konsumennya mengingat hak-hak konsumen telah diatur di dalam UU Nomor 8 Tahun 1999.

\section{B. Metode Penelitian}

Penelitian ini merupakan penelitian hukum empiris atau sama halnya dengan penelitian nondoctrinal. Pada penulisan sosiologis atau empiris maka yang diteliti awalnya adalah data sekunder yang memberikan penjelasan mengenai penulisan penelitian hukum, untuk kemudian dilanjutkan dengan penelitian data primer di lapangan atau terhadap masyarakat (Soerjono Soekanto, 2014: 52). Data primer adalah data yang diperoleh secara langsung berupa keterangan-keterangan dan pendapat dari para responden dan kenyataan-kenyataan yang ada di lapangan melalui wawancara dan observasi (Bambang Sunggono, 2008 : 15). Data sekunder adalah data yang diperoleh dari studi kepustakaan dan mempunyai kekuatan hukum mengikat, yang terdiri dari bahan baku primer, bahan hukum sekunder dan bahan hukum tersier (Bahder Johan, 2004 : 23). Data yang telah terkumpul kemudian dianalisis dengan melakukan penafsiran gramatikal.

\section{Hasil Penelitian dan Pembahasan}

Dalam setiap perjanjian yang dibuat oleh para pihak pasti mengandung suatu hal yang disebut dengan "prestasi". Pengaturan mengenai prestasi dalam perjanjian dijelaskan pada Pasal 1234 KUHPerdata yang menyatakan bahwa: "Perikatan ditujukan untuk memberikan sesuatu, untuk berbuat sesuatu, atau untuk tidak berbuat sesuatu". Sebaliknya, wanprestasi adalah tidak memenuhi atau lalai melaksanakan kewajiban sebagaimana yang ditentukan dalam perjanjian yang dibuat antara kreditur dengan debitur (Salim HS, 2008: 180). Pengaturan mengenai wanprestasi ditemukan pada Pasal 1243 KUHPerdata yang menyatakan bahwa: "Penggantian biaya, kerugian dan bunga karena tak dipenuhinya suatu perikatan mulai diwajibkan, bila debitur, walaupun telah dinyatakan lalai, tetap lalai untuk memenuhi perikatan itu, atau jika sesuatu yang harus diberikan atau dilakukannya hanya dapat diberikan atau dilakukannya dalam waktu yang melampaui waktu yang telah ditentukan". Didasarkan pada Pasal 1338 Ayat (1) KUHPerdata, perjanjian yang telah dibuat oleh para pihak mengikat para pihak yang terlibat untuk mematuhinya. Tetapi dalam praktiknya seringkali para pihak tidak mematuhi kesepakatan perjanjian yang telah dibuat. Wanprestasi bisa terjadi pada kedua belah pihak perjanjian, baik itu penjual maupun pembeli, tetapi fokus penulis pada penelitian ini yaitu wanprestasi yang dilakukan oleh penjual sehinga menimbulkan kerugian bagi pembeli. Mengenai bentuk dari wanprestasi dalam suatu perjanjian, menurut Ahmadi Miru wanprestasi itu dapat berupa perbuatan: 
a. Sama sekali tidak memenuhi prestasi.

b. Prestasi yang dilakukan tidak sempurna.

c. Terlambat memenuhi prestasi.

d. Melakukan apa yang dalam perjanjian dilarang untuk dilakukan (Ahmad Miru, 2008: 74)

Konsumen adalah setiap orang atau individu yang harus dilindungi selama tidak memiliki kapasitas dan bertindak sebagai produsen (Siska Diana Sari, 2018 : 143). Dalam hal pelaksanaan Perlindungan Konsumen tentu didasarkan pada beberapa asas, hal tersebut telah dijelaskan pada Pasal 2 Undang-undang Nomor 8 Tahun 1999 tentang Perlindungan Konsumen yang menyatakan bahwa: "Perlindungan konsumen berasaskan manfaat, keadilan, keseimbangan, keamanan dan keselamatan konsumen, serta kepastian hukum". Asas-asas tersebut tentu saja bukan hanya sekadar kata-kata belaka, tapi mempunyai maksud dibaliknya yaitu:

1. Asas manfaat dimaksudkan untuk mengamanatkan bahwa segala upaya dalam penyelenggaraan perlindungan konsumen harus memberikan manfaat sebesar-besarnya bagi kepentingan konsumen dan pelaku usaha secara kebutuhan.

2. Asas keadilan dimaksudkan agar partisipasi seluruh rakyat dapat diwujudkan secara maksimal dan memberikan kesempatan kepada konsumen dan pelaku usaha untuk memperoleh haknya dan melaksanakan kewajibannya secara adil.

3. Asas keseimbangan dimaksudkan untuk memberikan keseimbangan antara kepentingan konsumen, pelaku usaha, dan pemerintah.

4. Asas keamanan dan keselamatan konsumen dimaksudkan untuk memberikan jaminan atas keamanan dan keselamatan kepada konsumen dalam penggunaan, pemakaian, pemanfaatan dan/atau jasa yang dikonsumsi atau digunakan.

5. Asas kepastian hukum dimaksudkan agar, baik pelaku usaha maupun konsumen menaati hukum dan memperoleh keadilan dalam penyelenggaraan perlindungan konsumen, serta negara menjamin kepastian hukum (Guanawan Widjaja dan Ahmad Yani, 2001 : 99 ).

Hak-hak yang seharusnya diterima oleh para konsumen menurut ketentuan pada Pasal 4 Undang-Undang Nomor 8 Tahun 1989 tentang Perlindungan Konsumen, yang menyatakan antara lain:

1. Hak dan kenyamanan, keamanan dan keselamatan dalam mengkonsumsi barang dan/atau jasa.

2. Hak untuk memilih barang dan/atau jasa serta mendapatkan barang dan/atau jasa tersebut sesuai dengan nilai tukar dan kondisi serta jaminan yang dijanjikan.

3. Hak atas informasi yang benar, jujur dan jujur mengenai kondisi dan jaminan barang dan/atau jasa.

4. Hak untuk didengar pendapat dan keluhannya atas barang dan/atau jasa yang digunakan.

5. Hak untuk mendaparkan advokasi, perlindungan dan upaya penyelesaian sengketa perlindungan konsumen secara patut.

6. Hak untuk mendapatkan pembinaan dan pendidikan konsumen. Hak untuk diperlakukan atau dilayani secara benar dan jujur serta tidak diskriminatif.

7. Hak untuk mendapatkan kompensasi, ganti rugi dan/atau penggantian, apabila barang dan/ atau jasa yang diterima tidak sesuai dengan perjanjian atau tidak sebagaimana mestinya.

Berdasarkan hasil penelitian oleh penulis, keseluruhan responden (konsumen) pernah mengalami wanprestasi ketika melakukan transaksi dengan Rich Richie Ride Garage. Namun terdapat perbedaan wanprestasi yang dialami oleh beberapa responden (konsumen). Berikut merupakan penjabaran wanprestasi yang pernah dialami oleh para responden bedasarkan pada klasifikasi wanprestasi menurut Ahmad Miru, antara lain: 
a. Sama sekali tidak memenuhi prestasi

Pada jenis wanprestasi ini walaupun jarang terjadi, tetapi bukan berarti tidak pernah terjadi. Hasil penelitian oleh penulis menemukan terdapat kasus dimana terdapat konsumen mengalami wanprestasi pada jenis ini ketika melakukan transaksi dengan Rich Richie Ride Garage. Dalam hal ini Rich Richie Ride Garage pernah tidak memberikan jasa custom yang sudah dipesan oleh konsumen tersebut. Pihak Rich Richie Ride Garage juga mengaku bahwa timbulnya permasalahan tersebut dikarenakan Konsumen yang tidak memberi kabar meskipun bahan motor sudah diserahkan ke bengkel. Dan dalam proses pengerjaan. Menurut pihak bengkel, hal tersebut terjadi dikarenakan konsumen tersebut tidak dapat memberikan uang di awal sesuai dengan mekanisme perjanjiannya, lalu konsumen tersebut tidak bisa diajak berkomunikasi oleh pihak bengkel, hingga akhirnya konsumen tersebut meninggalkan motornya di bengkel.

b. Prestasi yang dilakukan tidak sempurna

Wanprestasi pada jenis ini tidak sering dilakukan oleh Bengkel Rich Richie Ride Garage. Bedasarkan hasil penelitian yang dilakukan oleh penulis, para konsumen merasa terjadi ketidaksesuaian spesifikasi antara motor yang sudah jadi dengan apa yang dikehendaki oleh konsumen. Faktor utama yang mempengaruhi sebuah model penilaian evaluasi terhadap kualitas jasa adalah expected service dan perceived jasa, yaitu konsumen melakukan perbandingan service (Akbar, Mohammad Muzahid dan Noorhan Parvez. 2009: 42). Ketidaksesuaian spesifikasi tersebut paling banyak terjadi dalam hal aksesoris yang ditempelkan pada kendaraan konsumen.

c. Terlambat memenuhi prestasi

Dari hasil penelitian yang dilakukan oleh penulis, wanprestasi pada jenis ini merupakan yang paling sering terjadi pada Rich Richie Ride Garage. Keterlambatan dalam hal pengerjaan kustom motor ini sering terjadi saat banyak pesanan yang diterima oleh Rich Richie Ride Garage. Selain itu, banyaknya permintaan modifikasi oleh konsumen bertambah seiring dengan proses pengerjaan motor milik konsumen tersebut, biasanya jika terdapat tambahan bagian untuk dimodifikasi, para konsumen sadar akan tambahan biaya, namun kurang peka terhadap tambahan waktu pengerjaannya.

d. Melakukan apa yang dalam perjanjian dilarang untuk dilakukan

Bedasarkan hasil penelitian yang dilakukan oleh penulis, penulis tidak menemukan adanya wanprestasi pada jenis ini terhadap Rich Richie Ride Garage. Sehingga dalam hal ini penulis menyimpulkan walaupun wanprestasi pada jenis ini sangat jarang terjadi pada Rich Richie Ride Garage, tetapi hal ini bukan berarti wanprestasi pada jenis ini tidak mungkin untuk terjadi.

Mengenai perlindungan konsumen, penulis melakukan penelitian dengan wawancara kepada para responden dalam hal hak-hak yang diterima oleh konsumen, dan juga mengenai solusi atau proses penyelesaian apabila terjadi wanprestasi terhadap konsumen. Tujuan dari penulis untuk mengetahui kepemahaman konsumen mengenai hak-haknya dan juga untuk mengetahui dalam hal penggunaan jasa bengkel Rich Richie Ride Garage konsumen mendapatkan haknya secara keseluruhan atau tidak. Keseluruhan konsumen yang merupakan respondan pada penelitian ini merasa tidak mendapatkan hak-haknya sebagai konsumen secara keseluruhan. Penjual dan konsumen juga mengaku mengetahui akan adanya Undang-Undang mengenai perlindungan konsumen, tetapi yang disayangkan adalah para pihak tersebut tidak mengetahui isi dari UndangUndang terkait. Setelah mengetahui adanya hak-hak konsumen yang tidak terpenuhi, maka selanjutnya penulis menanyakan pada phak Rich Richie Ride Garage mengenai bentuk perlindungan konsumen yang diberikan. Pelaku usaha dalam hukum perlindungan konsumen harus dapat dimintakan pertanggungjawaban, yaitu jika perbuatannya telah melanggar hak-hak dan kepentingan konsumen, menimbulkan kerugian (Ni Komang Ayu, 2017 : 46) Dalam hal ini pihak Rich Richie Ride Garage memberikan bentuk pertanggungjawaban atas jasa modifikasi kendaraan milik para Konsumen dalam hal sebagai berikut: 
a. Rich Richie Ride Garage memberikan garansi reparasi/servis motor kustom yang telah dipesan apabila dalam jangka waktu tertentu motor kustom yang sudah sampai di tangan konsumen dirasa tidak sesuai/kurang nyaman saat digunakan oleh konsumen. Jangka waktu yang diberikan oleh Rich Richie Ride Garage selama 1 bulan.

b. Dalam hal terdapat kesalahan fatal dari pelaku usaha yang menyebabkan kerusakan parah pada kendaraan yang sudah dimodifikasi, pelaku usaha menyatakan siap untuk melakukan modifikasi ulang motor yang sudah dipesan konsumen. Sebagai contoh kesalahan fatal ini yaitu pelaku usaha yang lalai dalam hal pemasangan bagian dari mesin yang menyebabkan kerusakan pada mesin kendaraan milik konsumen ketika dikendarai.

Berdasarkan hasil dari wawancara yang dilakukan oleh penulis, Rich Richie Ride Garage memang menyatakan siap untuk memberi ganti rugi terhadap motor yang tidak sesuai dengan apa yang dipesan pembeli dikarenakan oleh kesalahan dari pelaku usaha. Namun di sisi lain dari para konsumen juga merasa terdapat hambatan ketika para konsumen menagih atas haknya tersebut. Dari hasil wawancara penulis, para konsumen mengaku hambatan tersebut terdapat pada proses penggarapan ulang modifikasi motor yang memakan waktu terlalu lama. Dari pihak pelaku usaha menjelaskan dalam hal melakukan modifikasi ulang motor kustom yang dirasa tidak sesuai memang membutuhkan waktu yang lama karena harus membongkar kendaraan yang sudah jadi tersebut untuk diketahui lebih jauh mengenai hal apa yang menyebabkan motor kustom yang sudah jadi bermasalah, sehingga dengan hal tersebut diharapkan motor kustom yang sudah dimodifikasi ulang tidak akan mendapatkan masalah lagi di kemudian hari. Hal ini tentunya memberikan kerugian bagi para konsumen karena para konsumen tidak bisa segera menggunakan motor yang sudah dipesan. Berdasarkan hasil penelitian yang dilakukan oleh penulis, dalam perjanjian jual beli barang atau jasa pada bengkel modifikasi Rich Richie Ride Garage terjadi wanprestasi yang merugikan para konsumen. Wanprestasi tersebut antara lain dalam hal keterlambatan proses modifikasi hingga waktu yang telah ditentukan dan ketidaksesuaian modifikasi dengan apa yang telah diperjanjikan. Konsumen melakukan perbandingan servis dari servis yang mereka terima (Fall, 1985 : 44). Pada perjanjian jual beli barang atau jasa pada bengkel modifikasi Rich Richie Ride Garage, penjual sudah memberikan mekanisme mengenai ganti kerugian yang dialami oleh konsumen. Ganti rugi yang diberikan oleh para penjual tersebut berupa refund atau dengan pembuatan ulang kendaraan yang sudah dipesan apabila motor yang dihasilkan mengalami kerusakan fatal akibat dari kesalahan penjual. Penjual juga memberikan garansi servis apabila motor yang sudah dimodifikasi dirasa kurang sesuai dengan apa yang dipesan konsumen. Bedasarkan ketentuan pada Pada Pasal 19 Undang-Undang Nomor 8 Tahun 1989 tentang Perlindungan Konsumen, Rich Richie Ride Garage dirasa sudah sesuai dalam memberikan ganti rugi terhadap wanprestasi yang merugikan konsumen. Tetapi sayang sekali dalam pelaksanaan pemberian ganti rugi oleh Rich Richie Ride Garage memakan waktu yang cukup lama, sehingga dalam hal ini konsumen tidak dapat segera menggunakan motor yang telah dimodifikasi. Pada prakteknya, dalam keadaan dimana pembeli merasa penjual melakukan wanprestasi sehingga menimbulkan kerugian bagi pembeli, dan penjual menyangkal atas hal tersebut. Maka dalam hal ini pembeli menanggung beban untuk membuktikan hal tersebut. Sehingga dalam hal ini diperlukan adanya pernyataan lalai atau yang biasa disebut dengan somasi. Pengaturan mengenai somasi terdapat pada Pasal 1238 KUHPerdata yang menyebutkan bahwa: "Debitur dinyatakan lalai dengan surat perintah, atau dengan akta sejenis itu, atau berdasarkan kekuatan dari perikatan sendiri, yaitu bila perikatan ini mengakibatkan debitur harus dianggap lalai dengan lewatnya waktu yang ditentukan". Dari hasil wawancara penulis, para konsumen prakteknya tidak memberikan somasi terlabih dahulu dalam hal memperoleh pertanggungjawaban dari penjual. Keberadaan somasi sendiri tidak selalu diperlukan, kecuali dalam keadaan berikut (J.Satrio, 1999 : 105) :

a. Bahwa tenggang waktu yang ditentukan dalam perikatan merupakan batas akhir;

b. Perikatannya adalah sedemikian rupa sehingga hanya dapat dipenuhi pada saat itu saja.

atas hal yang telah dijelaskan di atas, sangat dimungkinkan untuk para konsumen yang merasa dirugikan akibat wanprestasi yang dilakukan oleh penjual untuk melakukan gugatan tanpa 
didahului dengan somasi atau pernyataan lalai kepada penjual. Mengenai penyelesaian dalam hal terjadinya sengketa perlindungan konsumen, telah diatur pada Pasal 45 Undang-Undang Nomor 8 Tahun 1989 tentang Perlindungan Konsumen, yang menyatakan bahwa:

1. Setiap konsumen yang dirugikan dapat menggugat pelaku usaha melalui lembaga yang bertugas menyelesaikan sengketa antara konsumen dan pelaku usaha atau melalui peradilan yang berada di lingkungan peradilan umum.

2. Penyelesaian sengketa konsumen dapat ditempuh melalui pengadilan atau di luar pengadilan berdasarkan pilihan sukarela para pihak yang bersengketa.

3. Penyelesaian sengketa di luar pengadilan sebagaimana dimaksud pada ayat 2 tidak menghilangkan tanggung jawab pidana sebagaimana diatur dalam Undang-undang.

4. Apabila telah dipilih upaya penyelesaian sengketa konsumen di luar pengadilan, gugatan melalui pengadilan hanya dapat ditempuh apabila upaya tersebut dinyatakan tidak berhasil oleh salah satu pihak atau oleh para pihak yang bersengketa.

Di sisi lain, apabila debitur yang dituduh melakukan kelalaian dan dimintakan hukuman beserta pertanggungjawaban atas kelalaiannya dapat melakukan pembelaan diri dengan cara sebagai berikut :

1. Mengajukan adanya keadaan memaksa (overmacht).

Hal ini didasarkan pada ketentuan Pasal 1245 KUHPerdata yang menyebutkan bahwa: "Tidak ada penggantian biaya. kerugian dan bunga. bila karena keadaan memaksa atau karena hal yang terjadi secara kebetulan, debitur terhalang untuk memberikan atau berbuat sesuatu yang diwajibkan, atau melakukan suatu perbuatan yang terlarang baginya".

2. Mengajukan bahwa kreditor sendiri sebelumnya telah lalai (exeptio non adimpleti cintractus)

Adapun prinsip exception non adimpleti contractus ini diatur dalam Pasal 1478 KUHPerdata menyebutkan bahwa: "Si penjual tidak diwajibkan menyerahkan barangnya, jika si pembeli belum membayar harganya, sedangkan si penjual tidak telah mengizinkan penundaan pembayaran kepadanya".

3. Mengajukan pembelaan bahwa kreditur telah melepaskan haknya untuk menuntut ganti rugi (rechsverwerking)

Secara prinsip, yang dimaksud pihak kreditur melepaskan haknya atas tuntutannya kepada pihak debitur adalah bahwa pihak kreditur telah mengetahui bahwa ketika pihak debitur mengembalikan barang yang diperjanjikan, pihak kreditur telah mengetahui bahwa waktu pengembalian barang sudah terlambat selama seminggu.

\section{Simpulan}

Bedasarkan hasil dari penelitian dan kajian yang dilakukan oleh penulis dalam hal perlindungan konsumen, hak-hak yang dimiliki oleh para konsumen dalam menggunakan jasa modifikasi bengkel Rich Richie Ride Garage tercantum pada Pasal 4 Undang-Undang Nomor 8 Tahun 1989 tentang Perlindungan Konsumen. Perlindungan hukum bagi konsumen selain pada ketentuan Undang-Undang Perlindungan Konsumen, pada kenyataannya terdapat peraturan lain yang juga memberi jaminan perlindungan hukum bagi konsumen, seperti ketentuan pada Buku III KUHPerdata. Meskipun Rich Richie Ride Garage sudah memenuhi aspek dalam memberikan pertanggungjawabannya, namun dalam kenyataannya masih terjadi hal-hal yang dapat merugikan para konsumennya. Pada dasarnya konsumen sebagai pihak yang kedudukannya lebih lemah berhak untuk menuntut pertanggungjawaban kepada penjual apabila terjadi wanprestasi. Tetapi yang sangat disayangkan adalah ketidaktahuan para konsumen mengenai aturan hukum perlindungan konsumen menyebabkan para konsumen kurang memahami hak-hak yang seharusnya didapatkan. Bahkan, terdapat pula konsumen yang melepaskan haknya dalam hal penggantian ganti rugi oleh penjual dikarenakan ketidaktahuan konsumen akan hak perlindungan hukum bagi konsumen. 


\section{E. Saran}

Menurut penulis sebelum melakukan perjanjian alangkah baiknya masing-masing dari para pihak mematangkan terlebih dahulu mengenai konsep/ide modifikasi, hambatan-hambatan dalam proses modifikasi, biaya yang ditimbulkan, serta hak-hak dan kewajiban bagi pihak bengkel maupun konsumen agar tidak terjadi miskomunikasi atau hal-hal yang tidak diinginkan. Bagi pihak bengkel sebaiknya terbuka dan secara jelas memberikan informasi kepada konsumen mengenai jasa yang akan ditawarkan kepada konsumen serta dapat memberikan masukan yang membuat para konsumen tetap memiliki motor modifikasi yang sesuai dengan peraturan yang telah ada, jangan terlalu percaya diri memberi janji kepada para konsumen untuk meminimalisir hal-hal yang tidak diinginkan, lebih bertanggung jawab dalam memberikan kompensasi apabila terjadi komplain dari konsumen agar tidak menambah rasa kecewa konsumen. Sedangkan pihak konsumen sebelum melakukan modifikasi motor alangkah lebih baiknya menyusun konsep modifikasi yang akan diterapkan secara matang, dan mempertimbangkan arahan dari pihak bengkel sehingga kendaraan yang dimodifikasi sesuai dengan aturan yang berlaku. Selain itu pihak konsumen sebaiknya mengerti secara keseluruhan mengenai hak-hak perlindungan yang didapatkan.

\section{F. Daftar Pustaka}

Budi Harto, 2015, "Analisis Tingkat Kepuasan Pelanggan dengan Pendekatan Fuzzy Servqual dalam Upaya Peningkatan Kualitas Pelayanan" Jurnal TEKNOIF Vol. 3 No. 1 : 2338-2724. Padang : Institut Teknologi Padang

Fall, 1985, "A conceptual model of a service quality and its implications for future" research. Journal of Marketing Vol.49. No. 4. American Marketing Association

Mohammad Muzahid Akbar dan Noorhan Parvez, 2009, "Impact of Service Quality, Trust, and Customer Satisfactionon Customer Loyalty”. ABACJournal Vol. 29 No. 1. Bangkok: Assumption University

Munjiati Munawaroh. 2005, "Analisis Pengaruh Kualitas Jasa terhadap Kepuasan pada Industri Pendidikan di Yogyakarta". Jurnal Siasat Bisnis, ISSN: 0853 - 7665. Yogyakarta: Universitas Muhammadiyah Yogyakarta

Nasution, Bahder Johan, 2004, Metode Penelitian Ilmu Hukum, Bandung, Mandar Maju.

Ni Komang Ayu Nira Relies Rianti. 2017,"'Tanggung Jawab Pelaku Usaha terhadap Konsumen dalam Hal Terjadinya Hortweighting Ditinjau dari Undang-Undang RI No 8 Tahun 1999 tentang Perlindungan Konsumen" Jurnal Magister Hukum Vol. 6, No. 4 : 521- 537. Denpasar: Universitas Udayana

Salim HS, 2008, Pengantar Hukum Perdata Tertulis (BW), Jakarta, Grafika.

Sunggono, Bambang, 2008, Metodologi Penelitian Hukum, Bandung, Rajawali Pers.

Wahyu Simon Tampubolon. 2016,"Upaya Perlindungan Hukum bagi Konsumen Ditinjau dari UndangUndang Perlindungan Hukum" Jurnal IImiah "Advokasi" Vol. 4, No. 1 : 2337-7216. Medan: Universitas Sumatra Utara 